\title{
7
}

\section{PRIVATE Friends and Public Citizens}

Like education, friendship improves the quality of life by requiring virtue (NE 1155a3-4). Also like education, friendship is a public and a private good; neither cities nor individuals can live well without it. Thus, contrary to the modern view, Aristotle believes that friendship is properly the concern of political science. He says not only that friendship should be a concern of legislators but, in further contrast to the modern perspective, that it is a necessity (1155a4-5). Not only can regimes and individual human beings not live well, they cannot survive, without friendship. That political orders require offices or a system of ruling in order to last implies, in fact, that they require friendship of a sort. In this chapter I explain the types of public and private friendship Aristotle deems essential to a regime and to an individual human life.

\section{FRIENDSHIP DEFINED}

After observing that friendship is both a necessity and a good, Aristotle continues his introduction to the subject in the Nicomachean Ethics with several other observations, with a view to defining friendship (1155b13-18, 28-1156a5). First, friendships differ with respect to not simply the amount but also the kind of affection or love involved. We can tell what kind of affection a friendship involves, or what kind of friendship it is, by the object or end toward which it is directed. Also relevant to defining friend- 
ship is whether the affection is reciprocated. If it is not, then the relationship is not friendship (for we do not say there can be friendship with wine, with someone whom one does not know, or with someone who is not aware of one's affection).

Reciprocity as a criterion of friendship is, however, problematic in that among examples of kinds of friendship are the relationship between parents and offspring and that among citizens, or "concord" (NE 1155a16-26). It is not evident that infants or all children reciprocate affection or that all citizens know one another. Indeed, Aristotle says much later that we should set apart relationships between relatives and those between citizens from the other sorts of friendship (1161b12-15). Yet, that he uses these examples to introduce the subject of friendship and takes them up later seems to indicate that we should not set them apart from other sorts of friendship. Apparently, that they may be characterized by an absence of reciprocity does not sever them entirely from the category of friendship. Moreover, as human beings know from experience, and as Aristotle will say, reciprocity is sometimes a feature of both of these kinds of relationships (in good families and among good men who are citizens). The question arising then is, what more clearly both qualifies and disqualifies kinship and concord as friendship? Perhaps Aristotle believes that they each qualify as friendship because they are the relationships that perpetuate cities but do not qualify insofar as neither kind of relationship is chosen. ${ }^{1}$

According to Aristotle, only three kinds of friendship are reciprocal-friendships of utility, of pleasure, and of virtue ( $N E$ 1156a7-10). The first form when persons discover that they can supply each other with useful things; the second, when parties find pleasure in one another; and the third, when people love one another for the other's self or character. Yet human beings regard as useful what seems good or pleasant to them (1155b19-26). Thus, generally speaking, there are only two species of friendship. One yields pleasure and the other is good in itself.

On one hand, then, Aristotle's introduction to friendship appears to serve the purpose of simplifying a complex topic. It introduces five species of friendship-kinship, concord, utilitarian 
friendship, pleasure-based friendship, and true friendship-but gives the impression that there are only two categories of friendship. On the other hand, relative to what follows, the introduction seems misleading and incomplete. Aristotle teaches later that kinship and concord are not negligible forms of relationship and that there is a sixth sort of friendship-namely, friendship with oneself. Perhaps one should regard Aristotle's introduction as neither a simplification nor an oversimplification of what is to come but as a statement to the effect that, of all the sorts of friendship, the two that are most properly speaking friendships are those that are both chosen and private.

\section{KINSHIP}

Although friendships founded on pleasure and virtue appear to rank at the top of Aristotle's hierarchy, friendship with relatives or kinship is first, in time, for human beings. Our first friends are our parents and siblings. Aristotle observes this, in effect, at the beginning of the Politics, by describing the household as being prior to the city in time.

Our first friendships, then, are characterized by inequality. Each household member has a different virtue (aretē) and a different function (ergon) and, consequently, "each does not get the same thing from the other" (NE 1158b17-20). Indeed, it is clear that the benefits a child receives from its parents far exceed those the parents receive from the child. Most notably, the child receives its very being from the parents-or, more specifically, from the father. But the child also receives nurture and education (NE 1161a16-17). In contrast, the child can reciprocate at first merely by being the likeness that its parents sought to bring into being (in order to leave behind) (Pol 1252a28-30). Somewhat later, children can reciprocate by honoring, obeying, or loving their parents (NE 1161b24-26). But it seems that offspring cannot reciprocate in any other way until they are adults, for only then can they provide their parents with means of support and present what they have made of themselves to them (that one's offspring is prospering seems to be for some mothers a sufficient return) (NE 1165a21-23, 1159a28-33). By showing affection in these ways to their parents, offspring in a 
sense equalize the vast inequality between themselves and their parents (1159b1-2) and thereby render their friendship with them lasting and decent (epieikess) (1158b21-28).

Even apart from the latent effort to reciprocate on the part of the offspring, there is a sense in which household relationships are theoretically just, for the claims of justice are proportionate to desert (NE 1161a21-22). Aristotle implies that the balance of claims rather than the balance of actual benefits constitutes the essence of the household's justice (for offspring could never do enough to repay the debt of their existence; 1163b15-21).

In describing family relationships in terms of the worth, merit, or virtue of the parties, Aristotle indicates that they have, not rights against each other, but duties or responsibilities toward one another (NE 1159b35-1160a3, 1161a16-17). Parents have a duty to nourish and educate their children; children, to honor parents; brothers, to speak freely and share possessions with one another (1165a24-30). These duties are fulfilled naturally: "Parents love their children as part of themselves"; "children love their parents as the source of their beings"; and brothers love one another because they are born of the same parents, have the same upbringing, are similar in age and are (thus) equals (1161b18, 1161a3-5, 1161b30-1162a1, 9-14). Moreover, the natural feelings of the parents match, or enable them to fulfill, their greater duties (1161b1926, 1168a24-27, 1167b34-1168a9). Parents love their children more and more quickly than children do their parents, since they know with more certainty that their children are theirs than do the children know their parentage (hence also the reason mothers love their children more than fathers). Further, since children are a natural bond between parents, it is in the interest of their union to care for them (1162a19-25). In sum, perhaps Aristotle is saying that "there are, strictly speaking, no natural rights-only rights we confer upon each other out of natural inclination and commitment." 2

Aristotle acknowledges nonetheless that differences among family may arise when expectations are not met (NE 1163a24-26). Fathers may disown sons and brothers may hate each other ( $N E$ 1163b18-19, Pol 1328a15). Indeed, since the claims among intimates

2 Nel Noddings, Caring: A Feminine Approach to Ethics and Moral Education (Berkeley: University of California Press, 1984), 120. 
are great, there is a chance that some will feel slighted (Pol 1328a14). It appears, however, that family members should strive to do what they can to acknowledge or return benefits received ( $N E$ 1163b15-18). That one's duties may be imposed by nature, rather than freely chosen, does not then seem in Aristotle's eyes to warrant failing to fulfill them. In other words, the household demands upholding virtue.

\section{FRIENDSHIPS OF UTILITY}

In comparison to his generally sanguine and inspiring portrait of kinship, Aristotle's description of ordinary friendship is cynical, or at least true to life. At the same time, he indicates that even common friendship has standards that the parties should try to meet.

Most people befriend others because they perceive a benefit to be obtained by doing so (NE 1156a10-12). Such friendship derives, then, from a felt or perceived need or lack (1159b12-14). Since people's needs and wants change, and their ability to fulfill the needs and wants of others changes, these friendships are characteristically always coming in and out of being (1156a20-24, 1158b4, $1159 \mathrm{~b} 10-11$ ). But there is nothing absurd (ouden atopon) about this; it is in fact reasonable (eulogon) that affection should cease when the attributes that we loved exist no longer (1165b1-4). Yet, that Aristotle takes pains to point out that it is not strange for such friendships to die suggests that parties to these friendships are often disappointed or shocked when they do. Aristotle's remark reveals, in other words, that the many do not want their friends to change, for even the betterment of a friend may threaten his or her usefulness to another.

The durability of utilitarian friendships is apparently a function, not only of the presence of desired attributes in the friends, but also of whether the respective ends sought are the same and whether the ends derive from the same source (NE 1157a3-6). A friendship in which the ends sought are not the same is especially fragile; if only one of the two different needs from which the friendship arose ceases to exist, then so does the friendship. For example, a person without a car seeks transportation to work, a fellow employee with a car seeks someone to talk to on the way; if the first gets his own car, then for him the utility of the friendship 
disappears. If, however, they both seek conversation for the drive, then they continue to ride together even if they both have cars. But if one wants to talk only about sports and the other only about politics, then their ride sharing does not last long. By contrast, if two people both seek entertainment on Saturday evenings (the same end), and both want to play cards (they find entertainment in the same source), then the friendship has prospects for continuing. In this respect friendships of utility do not differ from other sorts of friendship: the more the parties are alike, the longer the friendship lasts (1158b1-3).

Those who are friends for the sake of utility tend not only to terminate eventually (in spite of their wishes) their association ( $N E$ 1157a14-15) but also to distrust one another (1157a20-24); to prefer not to live together (1156a27-28); and to accuse and reproach each other (1162b5-6). But this, again, is reasonable or to be expected (eulogos), "for these friends deal with each other in the expectation of gaining benefits. Hence they always require more, thinking they have got less than is fitting" (1162b16-18). Furthermore, base or inferior people (phauloi) tend to form friendships of utility or pleasure, since they are not able to like one another for their characters (1157b1-3). On the one hand, these observations characterize friendships of utility in a negative way and seem even to contradict Aristotle's opening assertion that "friendship is a virtue or involves virtue" (1155a3-4). Aristotle admits in fact that those who associate for the sake of utility are friends only by analogy or similarity, "for it is in virtue of something good and something akin to what is found in true friendship that they are friends" - that is, since pleasure, utility, and equality also characterize true friendship (1157a30-32, b4-5, 34-1158a1, 33-34). On the other hand, Aristothe says that those who tend to form friendships of utility are the old, the young, those in their prime, the rich, the poor, those in positions of authority, the clever, those who desire honor, the ignorant, the learned, the beautiful, the ugly, young lovers, those in mourning, those who do business, gift givers, and cities (1155a616, 1158a27-33, 1159a18-21, b11-16, 1162b25-34, 1171a29-30). Thus, friendships of utility are necessary to living. Aristotle tempers his more negative comments about friendships of utility also by suggesting that, even in these associations, standards of conduct should obtain: "If we can we should return the equivalent of what we have received . . . or even more" (1163a1-2, 16-20, b15- 
18). This would be just; for then people would be compensated for what they lack (1163b1-5).

\section{Friendships of Pleasure}

Friendships of utility may yield pleasure and have other things in common with friendships of pleasure, but they are not the same species of friendship as the latter (NE 1157a33-35). Friendships of pleasure are similar to those of utility in that they too tend to dissolve if what yields pleasure ("the bloom of youth," for example) passes away. Pleasure-based friendships are, however, much closer to true friendship because "both parties get the same things from each other and delight in each other or in the same things" (1158a18-20). Such friends give each other willingly and generously the pleasure they both find satisfying, and they rarely accuse or complain, "for both of them get what they want at the same time if they enjoy spending their time together; and someone who accused his friend of not pleasing him would appear ridiculous, when he is free to spend his days without the friend's company" (1162b13-16). Moreover, everyone, even people who have everything, needs pleasant friends or pleasure; people "wish to live with someone" (1158a23, 1155a5, 1171b27-28). Evidently, this category of friendship includes romantic love and erotic passion (1156b1-3, 1157a12-14, 1158a11-12).

Friendships of pleasure not only are very close to true friendship, they also may become true friendships. Romantic or erotic liaisons are apparently more likely to become so, for "many [lovers] remain friends if they have similar characters and come to be fond of each other's characters from being accustomed to them" (NE 1157a1012). Similarly, the natural inclination of men and women to form couples-which generally yields useful and pleasurable partnerships (since each sex has its proper virtue) - may also eventuate in friendships based on virtue (aretē) if the parties are decent (epieikeis) (1162a16-17, 24-27). ${ }^{3}$ Aristotle seems to discourage any dis-

3 It is therefore misleading to say, as does Jean-Claude Fraisse, that "Aristotle dispels all assimilation between friendship and a passion, in the modern sense of the word. If philia is not a pathos, to the extent to which it is not passive, it is still less a fit of passion, or, like Platonic eros, a form of mania, of delirium"; see Philia: La Notion d'amitié dans la philosophie antique (Paris: Librairie Philosophique J. Vrin, 1974), 
tinction between a person's qualities and character, both of which may give one pleasure, when he points out in Book I of the Politics the apparent mixing by nature of the various kinds of souls with various kinds of bodies (1257b27-39). It is futile to try to establish what falls under the category. of qualities and what under that of character because it is "not easy to see the beauty of the soul" (1254b38-39). Only when nature fulfills its intention of uniting beautiful bodies and beautiful souls (1254b27-28) is beauty of body an indicator of beauty of soul; but in that case, as Harvey C. Mansfield, Jr., implies, it remains difficult, or is especially difficult, to separate bodily from soulful qualities because the former distract one from the latter. ${ }^{4}$ In any case, loving or taking pleasure in the qualities along with the character of a person does not diminish that love precisely because a person's qualities are a part of him or her. Accordingly, in seeking partners people should "seek friends who are good as well [as pleasant], and good for them too; for then they will have everything that friends must have" (NE 1158a26-27).

Aristotle's portrait of friendships founded in pleasure stands in some contrast to his description of utilitarian friendship. Still, neither of these sorts of friendship is in itself good or bad: "It is possible for bad people as well [as good] to be friends to each other for pleasure or utility, for decent people to be friends to base people, and for someone with neither character to be a friend to someone with any character" (NE 1157a16-18). Aristotle is not denouncing either friendships of utility or those of pleasure but saying perhaps that one should enter into these friendships at the right time, with the right people, and in the right way ( $N E$ 1106b19-24, 1104b25-26). If so engaged in, private relations afford opportunities for gain, pleasure, and virtue.

198. Indeed, as Klaus Oehler explains, "pleasure plays such an important role in Aristotle's analysis of life, because in his eyes pleasure indicates the very existence of life and makes contact with an ultimate reality and hence, in describing the highest form of existence as a living thing, he comes to the conclusion that its activity is pure, uninterrupted pleasure." Moreover, "all beings strive for pleasure following a divine element in their nature. In doing so they are striving for a higher degree of self-awareness and self-knowledge, because pleasure is experience of life itself"; see "Aristotle on Self-Knowledge," Proceedings of the American Philosophical Society 118, no. 6 (1974), 505.

4 Taming the Prince: The Ambivalence of Modern Executive Power (New York: Free Press, 1989), 308-9 n. 31. And Mansfield, pointing out that the Greek work kalos can mean "noble" or "beautiful," suggests that in Aristotle's view "beauty of soul is not separable from beauty of body" $(66,308 \mathrm{n}$. 31). 


\section{Self-Love: Public and Private Friendship}

It is perhaps the most private relationship of all that affords the greatest opportunity for virtue, and therewith pleasure. The person who truly loves himself "gratifies the most authoritative part of himself [heautou tō kuriōtatō], obeying it in everything" (NE 1168b30). A human being is, Aristotle explains, like a city or any composite whole insofar as that person seems to be, above all, the part that is able to direct or guide (1168b30-35); hence he who follows this part becomes or realizes himself. In short, the finest thing one can do for oneself is to live according to reason (kata logon or meta logou) $(1169 \mathrm{a} 5,1)$.

Most people, however, harbor two misconceptions about selflove. On the one hand, they think that true self-love means being satisfied with or approving of oneself. To love oneself is, in this view, to believe that one is decent (NE 1166b3-4). It means not being hard on oneself or believing that 'I'm okay.' ${ }^{5}$ But, Aristotle objects, if this were true self-love, then almost everyone could be said to have achieved it, for the many, "base though they are," also appear to approve of themselves (1166b2-3). On the other hand, people distinguish self-approval from self-love and equate the latter with selfishness. They reproach those who award themselves "the biggest share in money, honors, and bodily pleasures" (1168b15-17) and think that those people are displaying self-love. At the same time, the many think that being good to oneself means pursuing all opportunities for external goods; self-love is, in their view, self-gratification (thus, the many both reproach and indulge in selfishness). In Aristotle's view, the equation of self-love with selfishness has in particular corrupted the notion of self-love.

Aristotle agrees that greediness or common selfishness is reproachable but objects that it is not self-love properly understood (Pol 1263a41-b4). The selfish person aims to gratify only his desires and feelings, following the nonrational rather than the rational part

\footnotetext{
5 Martha Craven Nussbaum captures this disposition, which is popular to cultivate today: "I am dissatisfied with my life. I feel that I am not reliably exercising excellences that are valuable to me. . . . I join a religious group or go in for some fashionable kind of therapy, with the result that I emerge feeling quite at peace and contented with my state, although my objective situation has not improved"; "Shame, Separateness, and Political Unity: Aristotle's Criticism of Plato," in Essays on Aristotle's Ethics, ed. Amélie Oksenberg Rorty (Berkeley: University of California Press, 1980), 398.
} 
of his soul (NE 1168b19-23). A base man should not, therefore, be encouraged to love himself, "for he will harm both himself and his neighbors by following his base feelings" (NE 1169a14-15, 1130a57). He will harm others by taking from them or taking advantage of them; he will harm himself by being led now by this desire, now by that one.

The person who truly loves himself is not so conflicted. His composure results from knowing that a human being may secure the highest satisfactions or greatest rewards by doing what is reasonable and noble. Being one with himself (homognōmonei heautō), he in fact desires what is noble (oregesthai tou kalou) (NE 1166a13$14,1102 \mathrm{~b} 26-29,1169 \mathrm{a} 5-6)$. This means, generally, acting in accordance with the interests of one's friends and country (1169a18-20). It may mean giving up wealth or power, dying for the sake of others, or, most paradoxically, letting others instead have the opportunity to act nobly (1169a25-36). Perhaps most striking, such a human being (spoudaios) "will choose intense pleasure for a short time over mild pleasure for a long time; a year of living nobly over many years of undistinguished life; and a single noble and great action over many small actions" (1169a22-25). For such a human being, the private is anchorage for a noble life, the resource that makes self-sacrifice and public service possible.

One might say, then, that self-love is the most ambitious and greatest form of moral friendship in that it serves the public and the private. In mediating between the two, it bestows the greatest moral goods on both the city and the self-lover (NE 1169a8-11).

\section{TRUE FRIENDSHIP}

In choosing the Nicomachean Ethics to address the subject of friendship, Aristotle indicates that friendship is, in Jean-Claude Fraisse's terms, "not cosmological, not metaphysical, not even directly political, but specifically ethical, and this springs . . . from the sense itself of the word philia"; philia is possible only between one human being and another. ${ }^{6}$ Or, one might say, Aristotle reveals in his choice of the Ethics that friendship is a private activity:

6 Philia, 193, 195-96. 
it is untouched by rulers and legislators insofar as it can arise only from individual initiative and discrimination. For this reason, Aristotle is especially concerned to persuade human beings to pursue the best forms of friendship. Those who are virtuous should aspire to achieve true friendship - the third form of chosen friendship he discusses in Books VIII and IX.

What is true friendship? If a good man loves himself by obeying the rational part of his soul, and if, as Aristotle says, a good man's friend is "another self" (NE 1166a31-32, 1170b6-7), then maybe a good man accrues friends by inducing others to listen to his reason. This follows, however, only if the others are nonrational, for only then does the relationship mirror that found within the soul of a good man, which is a sort of friendship. And then it is necessarily a lesser friendship, like that between master and slave ( $\mathrm{Pol}$ 1255b13).

If a good man's friend is like the good man, then the friend too must be self-loving in the correct way, and being a friend to him must mean facilitating or not impeding the friend's being self-loving. Insofar as loving someone for being morally virtuous means loving that person for a stable, perhaps even permanent, quality (he d'arete monimon) characterized by right desire (NE 1156b12-13, 1139a22-23), it seems that a friend loves another for who the other is and does not want the other to change. Yet "life is action not production," from which one might infer that an active, changing friend would enhance life; moreover, it has been shown that lesser friendships depend on what friends produce for each other. Should human beings wish their friends to change or not, according to Aristotle? He answers, in effect, that one should wish a friend not to grow or develop in any way but to become more adept at taking into account moral considerations. Moral virtue is, after all, not only a state of character (NE 1106a11-12, 1157b6-7) but right action involving good deliberation. Acting well (eu prattein) depends on good deliberation (euboulia), which "is correctness of deliberation as regards what is advantageous, arriving at the right conclusion, in the right way, and at the right time" (NE 1142b27-28). The good man "judges everything correctly" and "sees what is true in each case" (NE 1113a29-30, 34). The good man loves another for the other's disposition to act well and ability to do so. Unconditional friendship is, then, an oxymoron. One 
may love a friend for who that friend is, but this includes the friend's capacity to enact his or her virtues and thus realize his or her potential.

Does true friendship prohibit failures in conduct? Must a friend, to remain a friend, always approve of one's conduct? According to Aristotle, true friendship may survive failures in conduct if they result from the agent's ignorance or if they are in fact only perceived failures. Virtuous agents usually do what virtue requires, but they may involuntarily act contrariwise, out of ignorancedoing neither the action they supposed, nor to the person, nor with the means, nor for the result they supposed (NE 1135a31-b2, 12-13). In contrast, "a voluntary act would seem to be an act of which the origin lies in the agent himself when he knows the particulars that the action consists in" (NE 1111a22-24). Only voluntary actions, then, are blameworthy (1135a20-21, b25). Thus, one may disapprove of a friend's inappropriate or unjust actions without ending the friendship because one sees that ignorance accounted for them-that the friend did not wish them at all (1113a17-18) - and that the conduct was thus an aberration. ${ }^{7}$

Friendship also entails appreciating that one may not know the reasons for or choices leading to a friend's conduct. Although one can judge another's character by the choices that person makes ( $N E$ 1112a1-2), to know what someone's choices are means knowing what deliberations went into them, for choice by definition involves deliberation (1112a15-16). If one does not know the reasoning and thought (logou kai dianoias) that went into someone's choices, then one can only hold opinions about those choices; "we opine what we do not quite know" (1112a8). Friendship requires openness to the possibility that one may not know the reasons, or all the reasons, for a friend's choices. Although among the virtuous a friend is like another self (NE 1170b6-7), moral virtue does not enable one to live a friend's life. Indeed, moral virtue entails recognizing that one cannot understand another's conduct just as the other does; thus, true friends give their friends the benefit of the doubt. Julia Annas's contention that Aristotle does not recognize

7 Confidence in another's character, which allows for such aberration, also renders friendship immune to slander; "for it is not easy to trust anyone speaking against someone who has been tested by oneself for a long time; and among good people there is trust, the incapacity ever to do each other wrong, and all the other things expected in a true friendship" (NE 1157a21-24). 
"the irrational element in friendship, which can lead us to like and love people of whom we strongly disapprove," leading, for Aristotle's conception of friendship accommodates the two vulnerabilities to which conduct, to the extent that it issues from choice making, is (perhaps inevitably) subject. Certainly we should infer that friendship thrives when friends approve of both the conduct and character of one another, but at the same time Aristotle gives us hope that it can survive at least the ignorance of the choice maker and the ignorance of the friend judging the choice maker. Indeed, friendship can withstand these because it is, in part, conviction that another has the capacity to make good choices. Just as one wishes oneself good and fitting things, such as health, wealth, and prosperity, because one believes one will use them well, so one wishes (though not quite as much) a friend good and fitting things because one believes that the friend will use them well (NE 1157b31-32, 1159a5-12, 1166a19-22). Friendship then includes, but is more than, feeling: "Love [philēsis] seems to be a feeling, friendship [philia] a fixed disposition; for love can be felt even toward soul-less things, but mutual love involves choice [proaireseōs], and choice springs from a fixed disposition" (1157b2831). ${ }^{9}$ The choice to enter into and sustain a relationship represents conviction about another's character.

8 "Plato and Aristotle on Friendship and Altruism," Mind 86, no. 344 (1977), 550.

9 There is debate over Aristotle's concept of proairesis (choice). The prevailing interpretation maintains that he uses the term both in exclusive reference to means and in reference to means that always aim at an end. The debate concerns the apparently contradictory claims that virtuous men choose actions for their own sakes (NE 1105a28-33, 1144a18-20) and that choice results from deliberation (bouleusis), which is always about how to achieve an end (NE III.2-3, VI.2); see Alfred R. Mele, "Choice and Virtue in the Nicomachean Ethics," Journal of the History of Philosophy 19, no. 4 (1981), 405-6. Arguing that choice is always toward (pros) ends, Mele notes Aristotle's claim that one can judge a man's character better by his choices than by his actions (NE 1111b5, 1110b31, 1117a5, 1163a22, 1164b1) and provides the following example: "Suppose that a just agent wants to do what is just in a situation in which he has, say, damaged a tool that he has borrowed. He deliberates, and judges that the just thing to do is to give the owner five dollars to cover the cost of repairing the tool (perhaps as opposed to buying the owner a new tool, or repairing it himself). Now, our just agent obviously does not give the owner five dollars simply for the sake of giving it to him: nor does he intend by giving him the money merely to bring it about that the tool is repaired. Rather, his primary intention in giving him the money is plainly to do what is just. . . Though our agent's giving the owner of the tool five dollars may not be a means (in the ordinary sense of the word) to his doing what is just, it is done with the intention of doing what is just, and, in this sense, is pros his doing what is just-that is, pros his end" (409). Although Mele's analysis is correct as far as it goes, it implies too narrow an 
Despite the vulnerabilities of conduct, it is, as noted, a good indicator of character in Aristotle's estimation. In fact, it seems that only the phenomena of aberrations and apparent aberrations in conduct allow one to see the difference between conduct and character. Aristotle would say, accordingly, that pressing the distinction between conduct and character any further is analytically overzealous.

It is difficult, if not impossible, not only to divide a person into constituent parts, but to distinguish loving another from loving oneself; "for the good man in becoming a friend becomes a good to his friend," so if one loves him, one is loving what is good for oneself (NE 1157b33-35, 1156b12-14). As W. D. Ross explains, Aristotle suggests "that the self is not a static thing but capable of indefinite extension. . . a man may so extend his interests that the welfare of another may become as direct an object of interest to

understanding of what Aristotle means by an end. According to Aristotle, a human being's end is a life lived well. Attaining this end may require doing more than what is just (for example, doing what is noble). What is more, one may not be able to judge, given a particular set of circumstances and apparent responses to those circumstances, whether an agent acted virtuously. Such a judgment may not even be possible before the agent has finished living, for a virtuous response may mean waiting for the right set of circumstances in which to respond.

Let us take two examples. Suppose one scholar borrows a copy of the Federalist Papers from another and, just before he returns it, spills coffee on it. Since the copy was full of the owner's marginal notations and underscoring, buying the owner a new copy or giving him money will not compensate for the damage done. The borrower thus chooses to do nothing but apologize. But he does so in hope of compensating later, in some way, for the mishap. It is in continuing relationships that a human being can be judged virtuous or not.

Another example illustrating that a virtuous person's end must be understood broadly as a life lived well is that of a student who judges himself indebted to his mentor. The student knows that gifts or invitations are only tokens of appreciation, not repayment for his mentor's years of advice, criticism, and recommendation letters. Indeed, he sees that he may come closest to repaying his mentor by living a life that reflects serious consideration of what his mentor has imparted to him.

Although a life lived well undeniably includes the realization of other ends (doing what is just in particular instances), it may take the course of a person's lifetime to reveal the goodness of that life and thereby of all the particular choices ( $N E$ 1098a18-20). In sum, according to Aristotle one aims at what is unconditionally complete, for an end worthy in itself of pursuit is more choiceworthy than "ends that are choiceworthy both in themselves and for the sake of this end" (NE 1097a2834). And the "absolutely final" end, which is always pursued only for itself and never as a means, is happiness, activity of the soul in accordance with virtue (1097b20-21, 1098a12-14). Hence "choice springs from a fixed disposition" (NE 1157b31). 
him as his own welfare."10 Yet, in loving him, one is helpful to him, gives him pleasure, and wishes him good things (1156b13-15, 1157b35-36). Indeed, friendship "seems to consist more in loving than in being loved" (1159a27-28, 33-35). Self-love that takes the form of loving another thereby compresses egoism and altruism. In Aristotle's view, only maternal love, and then apparently only in some cases, approaches selfless love (1159a28-33). One thus wonders if inequality permits selflessness. In any case, because the good are equal in virtue (1159b2-4), they are capable of fostering each other's virtue (and thereby, in effect, of returning virtue) $(1159 \mathrm{~b} 2-7)$, and because they are virtuous they try to return more than they receive.

The moral standards inherent in true friendship are, however, tacitly self-imposed, for "if one idolizes or imposes excessive moral demands on one's friends, one may well be betrayed unintentionally by the overburdened person."11 In fact, true friends do not demand even predictable behavior, but rather constancy of judgment (which may naturally generate an expectation of-but still not a demand for-predictability). In other words, to repeat, friendship depends on confidence in another's character. Having this confidence, one expects that the other will honor the friendship, and in this way only does a friend expect certain conduct (not to be lied to, humiliated, betrayed) from a friend. However,

these kinds of friendships are likely to be rare, since such people are few. Moreover, they need time and familiarity; as the proverb says, men cannot know each other till they have 'eaten [a peck of] salt together'; nor can they accept each other or be friends until

10 Aristotle: A Complete Exposition of his Works and Thought (New York: Meridian, 1959), 224-25. Similarly, though deeming Aristotle's view of friendship deficient in this regard, Gregory Vlastos states: "[Aristotle's] intuition takes him as far as seeing that (a) disinterested affection for the person we love-the active desire to promote that person's good 'for that person's sake, not for ours'-must be built into love at its best, but not as far as sorting this out from (b) appreciation of the excellences instantiated by that person; (b), of course, need not be disinterested and could be egoistic"; "The Individual as Object of Love in Plato," in Platonic Studies (Princeton: Princeton University Press, 1981), 33 n. 100. Thus, Vlastos and Julia Annas (acknowledging him), criticize Aristotle for not distinguishing between "loving a person for himself," "truly as an individual," and loving him "as a bearer of desired qualities"; see Annas, "Plato and Aristotle," 550.

11 Judith N. Shklar, Ordinary Vices (Cambridge: Belknap, 1984), 142. 
each appears worthy of friendship and has won the other's trust. Those who are quick to treat each other in friendly ways wish to be friends but are not friends, unless they are also worthy of friendship and know each other to be so; for though a wish for friendship may arise quickly, friendship does not. (NE 1156b2432)

\section{Alternative Conceptions of Political Friendship}

Whereas true friendship is difficult to achieve, civic friendship is not. Aristotle believes that the standards for public interpersonal conduct should be lower than those for private interpersonal conduct. At the same time, unlike some modern political philosophers, he does not think that civic relationships must be founded only on the lowest human common denominator. Presenting a concept of civic friendship that reflects the dual nature of man, Aristotle surpasses the attempts of political thinkers who followed him to provide a useful concept on which to model public relationships. A brief consideration of a sample of those attempts underscores the merits of Aristotle's conception.

The most notable attempt to define civic friendship after Aristotle's is St. Augustine's. The latter's formulation of Christian fraternity falls short of adequacy, however, because it does not characterize the relationships among most citizens. According to Augustine, only those who love God can love their fellows, love of God is a consequence of God's grace, and the blessed are few. Neither their reason nor their moral dispositions motivate the chosen to love others; rather, grace compels them to love others because they are children of God. ${ }^{12}$ To love one's neighbor is simply one way to show one's love of God. The motivation for fraternity must be one's love of God, not of men, for "if we love the world, it will separate us from the love of God which is charity. . . . Two loves there are, of the world and of God: if the love of the world dwells in us, the love of God can find no entrance. The love

12 Saint Augustine, The City of God, trans. Marcus Dods (New York: Random House, 1950), XIV.7, 448; see also Herbert A. Deane, The Political and Social Ideas of St. Augustine (New York: Columbia University Press, 1963), 80. 
of the world must depart, the love of God come in to dwell: make room for the better love."13

Since "love of the world" dwells in most men, they do not reciprocate the love the blessed show to them. The best that can come from lovers of this world is a love of earthly glory. According to Augustine, this sort of love should not be wholly denounced, for it manifests a capacity to defer gratification, a quality needed also by Christians. It parallels the Christian temperament also in being mindful of the judgment of others. But this merit of the love of glory is at the same time its significant weakness, for it makes it "the slave of human praise"; that is, consciousness of the judgment of other human beings easily becomes pride, "the beginning of sin." The earthly city should therefore not promote the love of glory as civic virtue. ${ }^{14}$

In fact, Augustine dashes all hope of any semblance of virtue becoming the norm. In his estimation, the lovers of this world want "to draw the others into punishment with them." Being "by the contrariety of their aims . . . enemies to those who turn unto God," they try to deceive and seduce them into loving the things of this world. ${ }^{15}$ The wicked not only try to diminish the fraternity existing among the good but create conflict among each other in their quests for power and possessions. Men are not even simply social or political, for original sin made them grasping. Therefore, according to Augustine, the norm can never be either true virtue or civic virtue; rather, misery will prevail. ${ }^{16}$

St. Thomas Aquinas provides a more sanguine portrait of Christian civic virtue, but since he draws heavily from Aristotle his conception of civic friendship does not represent well an alternative to Aristotle's. Turning to Machiavelli, however, one finds a unique conception of political friendship. Yet, on inspection, one discovers that it suffers from one of the same defects as Augustine's-namely, that it cannot be a widespread phenomenon. Whereas in Augustine's view political friendship can exist only

13 Augustine, "In Epistolam Ioannis ad Parthos Tractatus Decem," II.8, as cited in Deane, Ideas of St. Augustine, 260-61, n. 85; see also City of God, XIV.28, 477.

14 City of God, V.15-19, 165-73; XII.6, 385; XIV.13, 460-62; quotations from V.19, 173 (emphasis added) and XII.6, 385.

15 From several works by Augustine; see Deane, Ideas of St. Augustine, 261 nn. 87, 91; text reprinted on page 32.

16 Augustine, City of God, XV.4, 481-82; see also Deane, Ideas of St. Augustine, 33, 260 n. 79. 
among the elect, in Machiavelli's view it can exist only between ruler and ruled. According to Machiavelli, a truly great leader knows how "to give men a feeling of security and win them over with the benefits he offers." He should elicit the support (favore), indeed, the friendship (amico) of the common people by comforting his subjects (for example, "with the hope that these bad times will not last long"), by defending them in bad times (a prince should always maintain his own arms and well-trained troops), and by being reservedly compassionate (a prince's conduct "should be of a sort tempered by prudence and kindness"). Indeed, criticizing Agathocles, who rose to political leadership by guile and bloodshed, Machiavelli says, "It cannot be called ingenuity to kill one's fellow citizens, betray friends, be without faith, without pity, without religion; all of these may bring one to power, but not to glory. . . . his vicious cruelty and inhumanity, together with his infinite iniquitous deeds, do not allow him to be counted among the most outstanding famous men." 17

Yet Machiavelli admits that he is really recommending that a prince merely seem good; it is harmful to be "compassionate, faithful, humane, upright, religious" but useful to appear to be so. Appearing to have these qualities rather than actually having them allows a prince to change "according as the winds of fortune and the fluctuation of things command him." To appear to be "all compassion, all faithfulness, all integrity, all kindness, all religion," one "must not separate himself from the good." 18 Yet this counsel is simply instructional, not intended to encourage a prince to pursue knowledge of the good for its own sake.

Moreover, Machiavelli indicates that a prince should win friends not only by insincere means but for insincere ends. He should seek the friendship of subjects and allies (that is, potential subjects) for assistance in adverse times and "as a ladder up" to more power in fortunate times. ${ }^{19}$

Political friendship requires, then, in Machiavelli's view, excep-

17 Machiavelli's "The Prince": A Bilingual Edition, trans. and ed. Mark Musa (New York: St. Martin's Press, 1964) VIII.74-75; IX.80-81; X.88-89; XIII.116-17; XVII.13637; VIII.68-69.

18 Ibid., XVIII.146-49.

19 Ibid., IX.80-81; Niccolò Machiavelli, The Discourses, ed. Bernard Crick, trans. Leslie J. Walker, S. J., rev. Brian Richardson (New York: Pelican Books, 1970), II.1, 273; see also Harvey C. Mansfield, Jr., Machiavelli's New Modes and Orders: A Study of the Discourses of Livy (Ithaca: Cornell University Press, 1979), 214-15. 
tional ability and exceptional power, excluding the ordinary from sharing in it among themselves. But even if citizens could achieve this kind of friendship, one would then have to consider the desirability of all citizens regarding one another as ladders to power-a thought that brings Hobbes's views to mind.

In Hobbes's Leviathan one finds the claim that men are disposed to fight one another for gain and glory. Whether they actually fight or not, "men have no pleasure . . . in keeping company, where there is no power able to over-awe them all." But even with a sovereign erected by the people to keep peace, men experience only sensations toward one another, not 'goodwill' or 'friendship.' Such are merely names designating whether we feel a desire or an aversion toward someone or something, and whether such objects are present or absent. To the extent that friendship exists among citizens, then, it is desire for society fulfilled, that is, "love . . for society" — which we name "kindness." Sounding somewhat like Machiavelli, Hobbes declares further that one of the main uses of speech is "to make known to others our wills and purposes, that we may have the mutual help of one another." Thus, kindness among Hobbesian citizens appears to arise when the need for transaction arises. ${ }^{20}$

This brief review should give an idea of the kinds of difficulty conceptions of civic friendship in the history of political philosophy present. Other philosophers present similar problems. One finds in Locke's "law of nature" and Rousseau's "general will" the basis of a kind of civic friendship, but one that arises, like Hobbesian kindness, by way of the affirmation of individual will. ${ }^{21}$ "Ethical life" for Hegel and "species life" for Marx include kinds of civic friendship, but like Augustinian fraternity they presuppose the transformation of human beings-not by grace, but by history or material circumstances. "Reason" must reconcile subjective interests with the common good, or the state must whither away. In summary, the weaknesses of these various conceptions of civic friendship are multiple and cross-cutting: some are limiting, mak-

20 Thomas Hobbes, Leviathan or the Matter, Forme and Power of a Commonwealth Ecclesiasticall and Civil, ed. Michael Oakeshott (Oxford: Basil Blackwell, 1946), XIII.81-82; VI.31-32, 35; IV.19.

21 On the essential affinity between Hobbes, Locke, and Rousseau, see Joseph Cropsey, "'Alienation' or Justice," in Political Philosophy and the Issues of Politics (Chicago: University of Chicago Press, 1977), 48. 
ing friendship the prerogative of the few (Augustine, Machiavelli); some volatile, making friendship essentially self-serving (Machiavelli, Hobbes, Locke); and others require the metamorphosis of human nature, making friendship unlikely (Augustine, Rousseau, Hegel, Marx). The ways Aristotle's conception surpasses these I leave largely for the reader to discern.

\section{Concord: Friendship among Citizens}

Political friendship includes a relationship among citizens and a relationship between rulers and ruled. That Aristotle discusses the first kind of political friendship, which he calls concord (homonoia), in the Nicomachean Ethics, and the second in the Politics, gives rise to the thought that friendship between rulers and ruled presupposes concord. In this section and the next I substantiate that speculation.

\section{Concord Defined}

In the middle of Book IX of the Nicomachean Ethics, Aristotle provides a concise operational definition of concord: a city is in concord if people are like-minded as to what is in their interest, choose the same means to effect their interest, and act on their common resolutions (1167a26-28). One should notice that concord is an attribute of a city (tas poleis homonoein). For concord to exist, "all together" or the whole, not every citizen, needs to be likeminded (1167a30-31).

General agreement need not be forthcoming about all matters, but only about important (megethei), practical matters (ta prakta), the interests and concerns of life ( $t a$ sumpheronta kai ta ton bion anékonta) which can in fact be resolved or realized (NE 1167a24-26, 28-30, b3-4). Thus, for concord to exist, citizens do not need to be in general agreement as to whether, for example, the earth is flat or spherical. This can be resolved, but neither its resolution nor whether people generally find its resolution persuasive bears on political life. Similarly, concord does not imply general agreement about whether an act of creation or evolution accounts for the existence of man, both because political order does not require it and because there appears to be no way to resolve it. Conversely, concord does imply general agreement as to the large practical matter of what the ends of political association should be: economic equality, empire, freedom or opportunity, order, safety, or 
justice, for example. Likewise, concord is general agreement not only about ends but also about means (1167a27): how many will rule, who is eligible to rule, how they will be selected, what prerogatives they will have, criteria for citizenship, what rights citizens will have, how disputes will be resolved, and whether and how these procedural matters can themselves be changed. But concord also implies acting on common resolutions (1167a28-31); that is, concord accommodates disagreement about ends and means which does not impede or prevent government from functioning. According to Aristotle's definition, disagreement among citizens about important constitutional matters constitutes discord only if it interferes with political operations such as the making and upholding of policy and elections. Hence "a city is in concord when the judgment of all decrees that offices should be elective, or they should form an alliance with Sparta, or that Pittacus should rule when he himself is willing" (1167a30-32). Pittacus must be willing to rule because otherwise the decree cannot be effected. 22 As long as faction does not obstruct government, a regime can be said to be in concord.

This condition does not mean, however, that where suppression succeeds there is concord; China was not in concord in 1988 nor was Romania in 1990 nor the Lithuanian Republic in 1991. Indeed, the act of suppressing signifies that dissent has and is interfering with actions of government. Moreover, in Aristotle's view, there cannot be political friendship where there is no justice ( $N E$ 1161a10-11, 32-34). But this condition does not imply either that governments should never suppress popular uprisings or should always enact the policies citizens want; rather, for there to be concord there must be justice (1161a10-11). Insofar as justice presupposes order, government should try to appease citizens, but to the extent that their demands contravene justice it should ignore them.

\section{The Nature of the Human Propensity for Concord}

One who disagreed with everyone about everything would be "like the man rebuked by Homer, 'clanless, lawless, hearthless'" (Pol 1253a4-5). Such a person would also be like Hobbes's man, for,

$22 \mathrm{H}$. Rackham contends that Pittacus must be willing because concord means unanimity and Pittacus would otherwise be a dissenting voice; see Aristotle: Nicomachean Ethics, rev. ed., trans. H. Rackham (Loeb Classical Library, 1934), 542, n. a; conceivably, however, Pittacus could vote against himself but agree to rule if elected. 
as Aristotle observes, "the one who is such by nature has by this fact a desire for war, as if he were an isolated piece in a game of chess" (1253a6-7). But such a person would be exceptional in Aristotle's view, for he maintains that human beings generally have a natural inclination to form cities, since alone they are not selfsufficient. They are, moreover, equipped by nature to form them, for the basis of cities is shared moral perceptions, and nature gives human beings both the capacity to perceive what is good and evil, just and unjust, and the capacity, in speech, to exchange those perceptions (1253a14-30). Aristotle is not saying that exchanging moral perceptions results necessarily in sharing them. Nor is he, as Alasdair MacIntyre contends, blind to "a Sophoclean insight-that it is through conflict and sometimes only through conflict that we learn what our ends and purposes are." 23 Aristotle defines judgment, what prudence effects, as "the right discrimination of the equitable" (NE 1143a20); in its attempt to discover what is equitable, good judgment addresses conflicting goods. Aristotle is not saying, however, as Bernard Yack contends, that because man has the capacity for argument he "is therefore an argumentative animal." Yack goes too far in criticizing MacIntyre's interpretation, contending that Aristotle maintains that political communities are based not on common moral perceptions but on argument about them. In Yack's view, Aristotle's citizens argue about "general standards of justice and goodness," about the very thing that, Aristotle implies, makes their disputation and decision making possible. ${ }^{24}$

Although human beings have the capacity for argument and do argue, Aristotle would say, they realize that it is in their self-interest to agree on at least general standards of goodness and justice. Concord does not require a human being to transform or rationalize his subjective will insofar as it allows for the expression of significant moral differences, which presupposes the retention of individual judgment. Concord cannot, however, accommodate "particularly violent distrust and conflict," for it would obstruct the autarky of citizens, that which the community should serve according to Aristotle. ${ }^{25}$

23 After Virtue: A Study in Moral Theory (Notre Dame: University of Notre Dame Press, 1981), 153.

24 "Community and Conflict in Aristotle's Political Philosophy," Review of Politics 47, no. 1 (1985), 97-98, 102, 105-6.

25 Yack, "Community and Conflict," 106; see also 102, 107, 109; see also Cropsey, "Justice and Friendship in the Nicomachean Ethics," in Political Philosophy, 262. 
The self-interested desire for concord is thus connected with a desire for privacy; one cannot achieve autarky without pursuing private activities, and the absence of concord makes private pursuits more difficult. Accordingly, by preserving and fostering privacy and private activities a regime promotes concord. Persons who enjoy personal friendships, family, household matters, business, the liberal arts, and contemplation do not invest their wellbeing in the political community; having less at stake in public matters, they are not inclined to violent confrontation. Citizens who, unlike Jason, know how to be private (Pol 1277a24-25) understand that the political community provides the means by which they may enhance life, not create it. ${ }^{26}$ This is why "concord is found among good men" (NE 1167b4-5). Each, being of one mind with himself, enjoys spending time in private, and thus agrees that privacy is a good (1166a23-24, 1167b5-6). What good men argue for in public, then, is the protection and provision of the private, opportunities and means to cultivate virtue.

\section{Rule: Friendship between Rulers and Ruled}

As citizens can be friends of a sort, so can rulers and ruled (NE 1161a11-14, 32-34). To establish the nature of ruling and the nature of the relationship between rulers and ruled, I next examine Aristotle's main thoughts on ruling, consider the ways his thoughts on justice inform and illuminate his understanding of ruling, and, with a view to clarification, compare his understanding of ruling with a prevailing modern conception.

\section{Ruling Defined}

Although the whole of the Politics concerns ruling, several statements in particular note its essential nature and fundamental features. In Book I, chapter 5, in his introduction to a discussion of slavery, Aristotle observes that ruling and being ruled are natural and confer benefits (1254a21-22). Moreover, "wherever something rules and something is ruled there is a certain work belonging to these together. For whatever is constituted out of a number of

26 As different as they are in other respects, Aristotle and Nietzsche both recognize that the political realm cannot be a source of true fulfillment; see, for example, Friedrich Nietzsche, On the Genealogy of Morals, ed. Walter Kaufmann, trans. Walter Kaufmann and R. J. Hollingdale (New York: Random House, 1967), 136. 
things - whether continuous or separate-and becomes a single common thing always indicates a ruling and a ruled element" (1254a27-31). Here Aristotle provides a kind of operational definition. There is ruling going on, so to speak, if there are "a number of things" (for example, body parts) and there is a recognizable unity or harmony about those things (for example, a human being). That he does not say what the certain work (ergon) belonging to the ruling and the ruled together is would seem to be because one cannot do so without knowing what kind of things the ruler and the ruled are. If, for example, the ruler is the intellect and the ruled the desiring part of the soul, then the work belonging to them is the satisfaction of both parts, or the best condition of the soul.

In the remainder of the fifth chapter of Book I, Aristotle gives the following examples of parts that constitute wholes and so evidence that ruling is at work: the soul and the body; the rational and the nonrational parts of the soul; man and other animals; male and female; and naturally superior and inferior human beings, generally speaking. Notably absent from this list are political rulers and citizens. Why does Aristotle leave out this apparently most obvious example? Evidently because "political rule is over free and equal persons" (Pol 1255b20). In the other cases, the natural superiority of one party over the other makes possible and desirable the activity of ruling.

What, then, makes possible the phenomenon of the free ruling the free? And what is the "certain work" belonging to and conferring benefits on both the ruling free and the ruled free? According to Aristotle, "among similar persons nobility and justice are found in [ruling and being ruled] in turn, for this is something equal and similar" (Pol 1325b7-8, 1287a16-18). To recall from my Chapter 3, he suggests, however, that political rule need not be rotational in order to be political rule; rulers may take into account the wishes of the ruled and in this sense "be ruled in turn" by them. ${ }^{27}$ The reciprocal aspect of political rule helps make it acceptable to the

27 Mary P. Nichols, Socrates and the Political Community: An Ancient Debate (Albany: State University of New York Press, 1987), 159. In fact, if one considers that human beings are much more likely to be unequal than equal to each other, the latter situation being a matter of chance or divine benevolence ( $P$ ol 1276b.37-38, 1295a28$29,1331 \mathrm{~b} 21-22)$, Aristotle seems to be cautioning against establishing rotational rule in claiming that "[to assign] what is not equal to equal persons and what is not similar to similar persons is contrary to nature, and nothing contrary to nature is noble" (Pol 1325b8-10). 
ruled free. Reciprocity is the certain work that confers nobility and justice on both the ruled and the rulers.

\section{The Status of Common Opinion}

Although political rule requires reciprocity, it depends even more on the exceptional virtues of rulers. Indeed, it might be observed that prudence, temperance, and justice precede and preside over reciprocity. They make ruling the noble and just institution of inequality. In other words, correct political rule confers more authority on the judgment of rulers than on the opinion of the ruled.

On the one hand, Aristotle seems to make the case that political rule requires mostly listening to the ruled, that this is what makes rulers and ruled friends. First, as I noted in Chapter 6, he implies that rulers should have the characteristics of the ruled, for ruling well presupposes having been ruled (Pol 1277b7-13). Likewise, a ruler's familiarity with particulars (hekasta gnōrizein) (NE 1141b14$15,1142 a 14)$ implies familiarity with common opinion. Finally, Aristotle seems to say that a ruler should be sympathetic to common opinion; to see what is fair, one has to show consideration for others (NE 1143a21-22).

On the other hand, he modifies these points. First, although ruling well presupposes having been ruled, only the prudent should rule (Pol 1277a14-16, 27-28) because only they recognize that the point of view of the ruled is only one of the two points of view that should be taken into consideration when ruling (1277b15-17). The other point of view is that of the ruler-the point of view of what is best for everyone in practice (NE 1141b1214, 1140b4-6, 20-21). So, although Aristotle indicates that judging what is equitable requires sympathy or consideration for others (suggnōmé), he immediately elaborates, pointing out that showing true consideration for others means discerning what is really equitable, not what they believe to be so (NE 1143a23-24). Rulers must take common opinion or the opinion of those involved in a particular situation into account, for prudence requires holding in view all particulars before issuing a decree; but in that prudence also requires meeting to the extent possible the demands of the good life in general, rulers must be willing to compromise, even abandon, opinion.

Thus, it is mistaken to suggest, as Ronald Beiner does, that judging what is equitable requires in Aristotle's estimation yielding to 
the viewpoint of those concerned. The source of Beiner's mistake is his assumption that citizens are in Aristotle's estimation normally morally virtuous or just. He regards as the usual case for Aristotle what Aristotle takes to be the exception. Hence Beiner writes: "A theory of political judgment leads irresistably to the formulation of a corresponding theory of friendship. To judge is to judge-with, to judge-with is to be a friend. To judge well is a staple of politics." Only when all citizens have prudence will judgment be judgmentwith. As Beiner himself acknowledges at the beginning of his account, prudence moves back and forth between the universal and particular; it does not conjoin with the particular. ${ }^{28}$

\section{Rulers: Representatives or Parents?}

It will be noticed that Aristotle's view of ruling contravenes the modern Western democratic view according to which what is best for the community necessarily represents common opinion. Ascertaining to what extent it contravenes this view, and its merits as an alternative, calls for a brief consideration of the modern concept of political representation.

There appear to be two conceptions of representation: disinterested and protective mediation. The first reflects the Latin origin of the word, repraesentare, which means "to make present or manifest or present again." ${ }^{29}$ I may represent you at the town meeting by simply repeating your views. But if three referenda are put forth, to continue to represent you I must judge which one you would support on the basis of the views you have expressed to me. This judgment would necessarily be, however, a judgment as to which referendum you should support. I cannot know which one you would support if you were there; I can only reason on the basis of your expressed views $X, Y$, and $Z$ which one you should support. Such representation cannot, then, be disinterested mediation. It must always involve the judgment of the representative. Accordingly, the original Latin meaning of representation "had nothing to do with agency or government." 30

Nonetheless, if the views put forth by a representative have little

28 Political Judgment (Chicago: University of Chicago Press, 1983), 73, 79-82; quoting 82 .

29 Hanna Fenichel Pitkin, The Concept of Representation (Berkeley: University of California Press, 1967), 241.

30 Ibid., 241; see also 209. 
or nothing to do with the wishes of particular persons, then, according to Hanna Fenichel Pitkin, "we leave the realm of representation altogether, and end up with an expert deciding technical questions and taking care of the ignorant masses as a parent takes care of a child." 31 That Aristotle does not think of rulers as experts deciding technical questions is evident from his arguing that their task is to prescribe not the legally just but the equitable. Almost anyone can merely apply laws, but it takes education, experience, and natural endowment to recognize and remedy their deficiencies. Aristotle's rulers represent the true interests of a community rather than the wishes of citizens, ${ }^{32}$ like good parents, but so do modern representatives. In other words, the question as to whether Aristotle's rulers are more like representatives or parents is misguided insofar as it presupposes a difference between their intentions.

Aristotle did not, then, fail to conceive the ruler as a representative in the strict sense because his linguistic repertoire lacked such a word, or because the age in which he lived was politically unsophisticated, but because he recognized the impossibility of neutral mediation. ${ }^{33}$ His work presupposes this rather than debates the possibility and merits of neutral mediation, because one cannot, as he says, deliberate about what cannot be otherwise ( $N E$ 1140a31-32); ruling and being ruled are natural (Pol 1254a21-22).

Aristotle reveals not only the naturalness but the desirability of ruling and being ruled ( $\mathrm{Pol} 1254 \mathrm{a} 22$ ). Governing should go beyond merely re-presenting opinions because they may not be reputable. The task of rulers is to rid politics of unreputable opinions. ${ }^{34}$ In Hannah Arendt's view, this definition degrades politics by precluding civic participation, the essence of freedom. ${ }^{35}$ Aristotle would perhaps respond that mandating respect for ignorance and turpitude is not freedom.

31 Ibid., 210.

32 This means, it should be noted, that they would consider the true interests of noncitizens as well.

33 According to Pitkin, the ancient Greeks had no word or concept corresponding to the word "representation" (Concept of Representation, 241).

34 Rulers thereby serve philosophers, who begin inquiry by considering reputable opinions (see Chapter 8, "Philosophical Inquiry," pp. 202-4).

35 The Human Condition (Chicago: University of Chicago Press, 1958), 196, 222-29; for the same contention, see Stephen Taylor Holmes, "Aristippus in and out of Athens," American Political Science Review 73, no. 1 (1979), 119. 


\section{Ruling and the Private}

Aristotle's view of the political role of common opinion brings the discussion to the familiar debate as to whether his political ideal is totalitarian, as Arendt and others charge. ${ }^{36}$ Aristotle would refute this charge at least by highlighting three features of his conception of ruling.

First, as noted, prudence compels rulers to listen to common opinion. Their aim is, not to impose their own views on all, but to discover and prescribe what is best for all. What is best may well incorporate the views of many or all. In any case, rulers do not aim to stifle the opinions of citizens, since they may be of help in the discovery of what is best for the political order.

Second, with political decision making the responsibility of rulers, not citizens, Aristotle's conception of ruling allows citizens to attend to their private affairs. Unlike rulers, they have the privilege of withdrawing from participation. Indeed, rulers have a responsibility to secure this privilege by preserving privacy and the means to use it well. Attending to private activities displays knowing how to be ruled, a virtue (Pol 1277a24-27, b25-27). A good citizen promotes the self-sufficiency of the whole by attaining selfsufficiency. Political participation is not the only way to make a civic contribution. Aristotle's conception of ruling thus opens a wider range of options to citizens than do political philosophies that conceive the political order as dependent on civic participation.

Third, although Aristotle does not grant rulers the prerogative of living private lives (NE 1130a2-3), he advocates their attending to some extent to their private concerns by noting that prudence includes doing what is good for oneself as well as what is good for the whole (NE 1141b29-1142a10). A person who does not exercise virtue in relation to himself will not be of service to the community. In sum, Aristotle argues that political friendship between rulers and ruled requires acknowledging and fostering the private.

36 See, for example, Holmes, "Aristippus." 